\title{
Acute myocardial infarction patients in the emergency department: factors influencing door-to-treatment time
}

A pessoa com enfarte agudo do miocárdio no serviço de urgência: fatores que influenciam o tempo de atendimento

La persona con infarto agudo de miocardio en urgencias: factores que influyen en el tiempo de atención

Sónia Oliveira de Matos Soares*; Paulo Alexandre Carvalho Ferreira**

\begin{abstract}
Context: In the context of acute myocardial infarction (AMI) management, mortality and morbidity rates increase as the symptom-onset-to-balloon time increases.

Objective: To analyze the door-to-treatment time (DTt) of AMI patients at the emergency department (ED) and to identify factors influencing DTt.

Methodology: Retrospective, quantitative, descriptive, correlational study. The medical records of 412 people who were admitted to the ED in 2014 and 2015 were analyzed.

Results: The results showed that $65 \%$ of patients had non-ST-segment elevation myocardial infarction (NSTEMI) and 35\% of them had ST-segment elevation myocardial infarction (STEMI). Door-to-electrocardiogram time was on average $1 \mathrm{~h} 40$. Of the 126 STEMI patients, 114 underwent primary percutaneous coronary intervention (PCI), with an average DTt of 7h19, and 12 underwent fibrinolysis, with an average DTt of $1 \mathrm{~h} 19$.

Conclusion: Age, smoking, absence of diabetes, type of transport, and period of admission to the ED were identified as factors influencing DTt.
\end{abstract}

Keywords: myocardial infarction; urgent care; nursing

\section{Resumo}

Enquadramento: No tratamento do enfarte agudo do miocárdio (EAM) à medida que o tempo entre o início dos sintomas e a reperfusão aumenta, a mortalidade e morbilidade também aumentam.

Objetivo: Analisar os tempos de atendimentos (TAtd) das pessoas com EAM que recorreram aos serviços de urgência (SU) e identificar fatores que influenciem esses tempos.

Metodologia: Estudo retrospetivo, quantitativo, descritivo e correlacional. Foram analisados os processos clínicos de 412 pessoas, admitidas no SU em 2014 e 2015.

Resultados: Obtivemos 65\% de pessoas com EAM sem supra desnivelamento do segmento ST (EAMSST) e 35\% com supra desnivelamento do segmento ST (EAMCST). O tempo entre a admissáo da pessoa e a realizaçáo de eletrocardiograma (ECG) foi em média de $1 \mathrm{~h} 40$. Das 126 pessoas com EAMCST, 114 realizaram intervenção coronária percutânea (ICP) primária com um tempo médio de 7 h19 e 12 realizaram fibrinólise com média de 1 h19.

Conclusáo: A idade, a presença de tabagismo, a ausência de diabetes, o tipo de transporte e o período de admissão no SU mostraram influência nos TAtd.

Palavras-chave: enfarte agudo do miocárdio; atendimento de urgência; enfermagem

*MSc., RN, Hospital Center of Leiria - District Hospital of Pombal, 3100-462, Pombal, Portugal [soniasoares013@gmail.com].Contribution to the article: literature search, data collection, data treatment, analysis, and discussion, and article writing. Address for correspondence: Rua Vale da Bica, no30, Carrascos, 3100-462, Pombal, Portugal.

**Ph.D., Professor, Nursing School of Coimbra, 3046-851, Coimbra, Portugal. Contribution to the article: literature search, data discussion, content revision.

\section{Resumen}

Marco contextual: En el tratamiento del infarto agudo de miocardio (EAM, en portugués), a medida que el tiempo entre el inicio de los síntomas y la reperfusión aumenta, la mortalidad y la morbilidad también aumentan.

Objetivo: Analizar los tiempos de atención (TAtd) de las personas con EAM que recurrieron a los servicios de urgencias (SU) e identificar los factores que influyen en esos tiempos.

Metodología: Estudio retrospectivo, cuantitativo, descriptivo y correlacional. Se analizaron los procesos clínicos de 412 personas, admitidas en el SU en 2014 y 2015.

Resultados: Se obtuvo el $65 \%$ de personas con EAM sin elevación del segmento ST (EAMSST) y el $35 \%$ con elevación del segmento ST (EAMCST). El tiempo entre la admisión de la persona y la realización del electrocardiograma (ECG) fue, de media, 1h40m. De las 126 personas con EAMCST, 114 se sometieron a una intervención coronaria percutánea (ICP) primaria con un tiempo medio de $7 \mathrm{~h} 19 \mathrm{~m}$, y $12 \mathrm{a}$ una fibrinólisis con una media de $1 \mathrm{~h} 19 \mathrm{~m}$. Conclusión: La edad, la presencia de tabaquismo, la ausencia de diabetes, el tipo de transporte y el período de admisión en el SU mostraron una influencia en los TAtd.

Palabras clave: infarto agudo de miocardio; atención de urgencia; enfermería

Received for publication: 14.06 .17 Accepted for publication: 03.11.17

Série IV - n. ${ }^{\circ} 15$ - OUT./NOV./DEZ. 2017 


\section{Introduction}

Acute myocardial infarction (AMI) is one of the most prevalent cardiovascular diseases (CVDs). It is fatal in approximately one-third of the patients and half of the deaths occur in the first hours after symptom onset (American College of Cardiology Foundation [ACCF] / American Heart Association [AHA], 2013). The European Society of Cardiology (ESC, 2012) recommends the implementation of a structured network based on pre-hospital diagnosis and rapid transport to a hospital with availability to perform primary percutaneous coronary intervention (PCI) since this is the ideal reperfusion strategy in case of ST-segment elevation myocardial infarction (STEMI), provided that it can be done expeditiously.

Accordingly, several organizations have been developing efforts with the purpose of identifying the main barriers and strategies to achieve a shorter intra-hospital response time. In view of this situation, the following objectives were set out: to analyze patients' sociodemographic and clinical characteristics and identify factors that influence the time elapsed between admission and diagnosis in AMI patients; to identify factors that influence the time elapsed between admission and treatment with primary PCI or fibrinolysis in STEMI patients.

\section{Background}

The number of people with AMI symptoms who use the Emergency Department (ED) every day varies. The same happens with the door-totreatment time (DTt), which can be influenced by multiple factors. Carapeto (2012) confirmed that the type of transport used to go to the ED influences DTt, showing that people who were transported by National Institute for Medical Emergencies (INEM, Instituto Nacional de Emergência Médica) ambulances received treatment quicker than other patients. DTt is also influenced by the period of the day and week when the person is admitted to the ED. DTt is longer at night (Magid et al., 2005) and during the weekend, which are times associated with increased mortality and a lower use of invasive cardiac procedures (Kostis et al., 2007).

In addition, epidemiological data on the last
50 years show a strong connection between CVDs and cardiovascular risk factors (CVRFs). Age and gender are the most analyzed non-modifiable CVRFs in the literature concerning their association with AMI. The Portuguese Directorate-General for Health reports that this disease mostly affects male patients aged 65 to 79 years. It also considers high blood pressure (HBP) as the non-modifiable CVRF with the strongest association with CVDs (Direção-Geral da Saúde, 2014). In a study conducted in Wisconsin (USA), Kanth, Ittaman, and Rezkalla (2013) concluded that the most common CVRF was HBP, followed by smoking and diabetes mellitus. However, no studies were found in the analyzed literature showing an association between CVRF and DTt, so this is a pioneer study in this area.

\section{Research question/Hypotheses}

What are the factors influencing DTt of AMI patients at the $\mathrm{ED}$, from admission to primary PCI?

$\mathrm{H} 1$ - There is an association between gender, age, and the time elapsed between admission and the ED and ECG;

$\mathrm{H} 2$ - There is an association between the presence of CVRFs (smoking, diabetes mellitus, HBP, dyslipidemia, overweight), cardiac history, and the time elapsed between admission to the ED and ECG;

$\mathrm{H} 3$ - There is an association between the period of the day/weekday of admission to the ED and the time elapsed until ECG;

$\mathrm{H} 4$ - There is an association between the type of transport to the ED and the time elapsed between admission and the ECG;

H5 - There is an association between the period of the day/weekday and the time elapsed between admission to the ED and the performance of primary PCI in STEMI patients.

\section{Methodology}

In view of the above, a retrospective, quantitative and descriptive-correlational study was conducted.

The selected population includes all patients diagnosed with AMI who were hospitalized 
in a hospital in the Center region of Portugal in 2014 and 2015. The following inclusion criteria were applied: patients aged over 18 years; the first visit to a hospital ED in this event; and patients admitted with a primary diagnosis of AMI. The following exclusion criteria were applied: patients who died at the ED before hospitalization; patients with secondary diagnosis of AMI; patients transferred from another hospital; patients referred by the urgent patient guidance center (Centro de Orientaçâo de Doentes Urgentes, CODU), sent directly to the hemodynamics unit (Via Verde Coronária); patients who suffered AMI during hospitalization. The study population was composed of 639 people, with 412 people being eligible for the sample. The sample was subdivided into NSTEMI $(n=266)$ and STEMI $(n=146)$ patients. With regard to the STEMI subsample, 12 people were treated with fibrinolysis, 114 with primary PCI, and the remaining patients were treated with conventional therapy or Coronary Artery Bypass Graft (CABG).

The data collection process involved the consultation of three software programs: Aplimed ${ }^{\odot}$ for collecting information on the emergency episode, SISCLI ${ }^{\ominus}$ for collecting information on the discharge note, and CardioBase ${ }^{\bullet}$ for collecting data on primary PCI.

Data were collected on patients' sociodemographic characteristics, including: age and gender; presence of CVRFs (smoking - current smoker, former smoker; alcohol consumption, diabetes mellitus - treated with oral anti-diabetic drugs [OADs] or insulin-treated patients; HBP, dyslipidemia, overweight); cardiac history (AMI, revascularized coronary disease, non-revascularized coronary disease, CABG, heart valve surgery, pacemaker); date and time of chest pain onset (in the past 24 hours); type of transport to the ED (INEM ambulance, medical emergency and resuscitation vehicle [Viatura Médica de Emergência e Reanimação, VMER]/ immediate life support [Suporte Imediato de Vida, ILS] ambulance, or own transport); date and time of admission to the ED; admission to the ED on Saturdays and Sundays; season of the year in which the patient was admitted to the ED (considering Winter between 22 December and 20 March, Spring between 21 March and 20 June, Sum- mer between 21 June and 21 October, and Autumn between 22 October and 21 December); in which the patient was admitted to the ED (divided according to nursing shifts: night [0H00-7H59], morning [8h00-15h59], and afternoon [16h00-23h59]); period of the day (divided into day period: $8 \mathrm{~h} 00-20 \mathrm{~h} 00$ [period of permanence of the cardiopulmonary technician at the ED] and night period: $20 \mathrm{H} 01-$ 7H59); date and time of triage; presentational flowchart and triage priority (using the Manchester triage system); date and time of the first ECG at the ED; diagnosis (classification in the discharge note, divided into STEMI and NSTEMI); type of treatment (divided into primary PCI, fibrinolysis, and conventional therapy or $\mathrm{CABG}$ ); date and time of fibrinolysis; date and time of primary PCI.

It should be noted that, since this is a retrospective study, not all of these aspects were recorded in every episode, leading to variations in the number of sampled patients, depending on the variable under analysis.

Data were exported to a database and statistically processed in Microsoft Office Excel ${ }^{\oplus}$. This database was subsequently transferred to a database in $\mathrm{IBM}^{\circledR} \mathrm{SPSS}^{\oplus}$ (Statistical Package for the Social Sciences), version 20.0 for Macintosh ${ }^{\oplus}$. This software was used for descriptive and inferential statistics, in which non-parametric tests were applied. In relation to univariate statistics, the Mann-Whitney $U$ test and the Kruskal-Wallis $\mathrm{H}$ test were used. Significance values were considered statistically significant at $p<0.05$.

All formal and ethical principles were met. Authorization was obtained from the Board of Directors of the hospital unit for conducting the study. Furthermore, the Ethics Committee of the Health Sciences Research Unit: Nursing of the Nursing School of Coimbra (UICISA:E) also gave a favorable opinion (Opinion no. 29406/2015).

\section{Results}

\section{Characterization of the sample}

The sample was composed of 412 people: 65\% with NSTEMI and 35\% with STEMI. Patients were aged 29 to 97 years, with a mean age (standard deviation) of 68.4 (13.7). Most of the sampled patients $(68.9 \%)$ were men (Table 1). 
Table 1

Absolute and percent distribution according to age and gender $(n=412)$

\begin{tabular}{lccc}
\hline Sociodemographic characteristics & $\begin{array}{c}\text { STEMI } \\
n=146\end{array}$ & $\begin{array}{c}\text { NSTEMI } \\
n=266\end{array}$ & $\begin{array}{c}\text { Total } \\
n=412\end{array}$ \\
\hline $\begin{array}{l}\text { Age, years, mean }(S D) \\
\text { [Min-Max] }\end{array}$ & $64.6(13.7)$ & $70.5(13.3)$ & $68.4(13.7)$ \\
$\leq 40$ years, $n(\%)$ & {$[29-94]$} & {$[35-97]$} & {$[29-97]$} \\
$41-50$ years, $n(\%)$ & $3(2.1)$ & $5(1.9)$ & $8(1.9)$ \\
$51-60$ years, $n(\%)$ & $28(19.2)$ & $16(6.0)$ & $44(10.7)$ \\
$61-70$ years, $n(\%)$ & $21(14.4)$ & $45(16.9)$ & $66(16.0)$ \\
$71-80$ years, $n(\%)$ & $44(30.1)$ & $56(21.1)$ & $100(24.3)$ \\
$\geq 81$ years, $n(\%)$ & $29(19.9)$ & $73(27.4)$ & $102(24.8)$ \\
Male gender, $n(\%)$ & $21(14.4)$ & $71(26.7)$ & $92(22.3)$ \\
\hline
\end{tabular}

Note. $S D=$ standard deviation; $n=$ sample; Min = minimum; Max = maximum.

With regard to risk factors, Table 2 shows that the most prevalent factor is HBP $(68.7 \%)$, followed by dyslipidemia (57.3\%). Table 2 also shows that $41.5 \%$ of patients were cur- rent or former smokers. As regards the cardiac history, $25.5 \%$ of the patients had cardiac history, with AMI (15.9\%) being the most prevalent condition.

Table 2

Absolute and percent distribution of the clinical characteristics $(n=412)$

\begin{tabular}{lccc}
\hline Clinical characteristics & $\begin{array}{c}\text { STEMI } \\
n=146\end{array}$ & $\begin{array}{c}\text { NSTEMI } \\
n=266\end{array}$ & $\begin{array}{c}\text { Total } \\
n=412\end{array}$ \\
\hline Risk factors, $n(\%)$ & & & \\
Current smoker & $50(34.2)$ & $52(19.5)$ & $102(24.8)$ \\
Former smoker & $24(16.4)$ & $45(16.9)$ & $69(16.7)$ \\
Drinks alcohol & $16(11.0)$ & $41(15.4)$ & $57(13.8)$ \\
Diabetic & $33(22.6)$ & $94(35.3)$ & $127(30.8)$ \\
$\quad$ Treated with OADs & $30(91.0)$ & $69(73.4)$ & $99(78.0)$ \\
Insulin-treated & $3(9.0)$ & $25(26.6)$ & $28(22.0)$ \\
Hypertensive (HBP) & $88(60.3)$ & $195(73.3)$ & $283(68.7)$ \\
Dyslipidemia & $82(56.2)$ & $154(57.9)$ & $236(57.3)$ \\
Overweight & $29(19.9)$ & $61(22.9)$ & $90(21.8)$ \\
Clinical history, $n$ (\%) & & & \\
Patients with cardiac history & $23(15.8)$ & $82(30.8)$ & $105(25.5)$ \\
AMI & $15(3.6)$ & $51(12.3)$ & $66(15.9)$ \\
Revascularized coronary disease & $2(0.5)$ & $7(1.7)$ & $9(2.2)$ \\
Non-revascularized coronary disease & $2(0.5)$ & $4(0.9)$ & $6(1.5)$ \\
CABG & $0(0.0)$ & $12(2.9)$ & $12(2.9)$ \\
Heart valve surgery & $3(0.7)$ & $4(1.0)$ & $7(1.7)$ \\
Pacemaker & $1(0.2)$ & $10(2.5)$ & $11(2.7)$ \\
\hline
\end{tabular}

Note. $n=$ sample. 
In relation to the transport used to get to the ED, only $69.9 \%$ of the files included this information. The majority of patients were transported by INEM (36.2\%). As regards the period of admission to the ED, most patients were admitted during the morning period $(42.7 \%)$. In relation to the season of the year, the distribution was balanced, with a slight increase in winter (Table 3).

Table 3

Absolute and percent distribution of assistance characteristics $(n=412)$

\begin{tabular}{|c|c|c|c|}
\hline Assistance characteristics & $\begin{array}{l}\text { STEMI } \\
n=146\end{array}$ & $\begin{array}{c}\text { NSTEMI } \\
n=266\end{array}$ & $\begin{array}{c}\text { Total } \\
n=412\end{array}$ \\
\hline \multicolumn{4}{|l|}{ Transport, $n(\%)$} \\
\hline INEM & $41(28.1)$ & $108(40.6)$ & $149(36.2)$ \\
\hline Own transport & $30(20.5)$ & $40(15.0)$ & $70(17.0)$ \\
\hline ILS + VMER & $31(21.3)$ & $35(13.2)$ & $66(16.0)$ \\
\hline Undetermined & & & $127(30.8)$ \\
\hline \multicolumn{4}{|l|}{ Period of the day/weekday, $n(\%)$} \\
\hline Night (0h00-7h59) & $34(23.3)$ & $70(26.3)$ & $104(25.2)$ \\
\hline Morning (8h00-15h59) & $72(49.3)$ & $104(39.1)$ & $176(42.7)$ \\
\hline Afternoon (16h00-23h59) & $40(27.4)$ & 92 (34.6) & $132(32.1)$ \\
\hline Weekend & $35(24.0)$ & $79(29.7)$ & $114(27.7)$ \\
\hline Day period (8h00-20h00) & $94(64.4)$ & $154(57.9)$ & $248(60.2)$ \\
\hline \multicolumn{4}{|l|}{ Season of the year, $n(\%)$} \\
\hline Winter & $31(21.2)$ & $89(33.5)$ & $120(29.1)$ \\
\hline Spring & $38(26.0)$ & $53(19.9)$ & $91(22.1)$ \\
\hline Summer & $35(24.0)$ & $62(23.3)$ & $97(23.5)$ \\
\hline Autumn & $42(28.8)$ & $62(23.3)$ & $104(25.2)$ \\
\hline
\end{tabular}

Note. $n=$ sample.

Table 4 shows that the vast majority of patients $(76.0 \%)$ was triaged by chest pain flowchart, followed by the shortness of breath $(10.7 \%)$ and unwell adult flowcharts $(7.3 \%)$. In relation to patients' pri- ority in triage, very urgent/orange was the most common (59.5\%), followed by urgent/ yellow $(30.9 \%)$. Together, these priorities account for $90.4 \%$ of the total number of triaged patients.

Table 4

Absolute and percent distribution according to triage $(n=412)$

\begin{tabular}{lccc}
\hline Triage & $\begin{array}{c}\text { STEMI } \\
n=146\end{array}$ & $\begin{array}{c}\text { NSTEMI } \\
n=266\end{array}$ & $\begin{array}{c}\text { Total } \\
n=412\end{array}$ \\
\hline Presentational Flowchart, $n(\%)$ & & & $313(76.0)$ \\
$\quad$ Chest pain & $115(78.8)$ & $198(74.4)$ & $8(1.9)$ \\
Abdominal pain & $2(1.4)$ & $6(2.3)$ & $44(10.7)$ \\
Shortness of breath & $11(7.5)$ & $33(12.4)$ & $3(0.7)$ \\
Diabetes & $1(0.7)$ & $2(0.8)$ & $30(7.3)$ \\
Unwell adult & $10(6.8)$ & $20(7.5)$ & $6(1.5)$ \\
Collapsed adult & $2(1.4)$ & $4(1.5)$ & $6(1.5)$ \\
Behaving strangely & $4(2.7)$ & $2(0.8)$ & \\
\hline
\end{tabular}




\begin{tabular}{lccc}
\hline Limb problems & $0(0.0)$ & $1(0.4)$ & $1(0.2)$ \\
Vomiting & $1(0.7)$ & $0(0.0)$ & $1(0.2)$ \\
Priority (triage), $n(\%)$ & & & $9(2.2)$ \\
Immediate/red & $3(2.1)$ & $6(2.3)$ & $245(59.5)$ \\
Very urgent/orange & $101(69.2)$ & $144(54.1)$ & $127(30.9)$ \\
Urgent/yellow & $35(24.0)$ & $92(34.6)$ & $29(7.0)$ \\
Standard/green & $6(4.1)$ & $23(8.6)$ & $2(0.4)$ \\
Non-urgent/blue & $1(0.7)$ & $1(0.4)$ & \\
\hline
\end{tabular}

Note: $n=$ sample.

Table 5 shows a mean time of $3 \mathrm{~h} 47$ between symptom onset and the admission to the ED, with a minimum of $0 \mathrm{~h} 06$ and a maximum of $23 \mathrm{~h} 15$. The mean time elapsed between admission and ECG was of $1 \mathrm{~h} 40$, with a minimum of $0 \mathrm{~h} 01$ and a maximum of $15 \mathrm{~h} 04$, being lower in STEMI patients, with a mean difference of 0h38. Only 12 people underwent fibrinolysis, with a mean time of $1 \mathrm{~h} 19$, a minimum of $0 \mathrm{~h} 37$ and a maximum of $2 \mathrm{~h} 24$. The mean door-to-balloon time (primary PCI) was of 7 h 19 , with a minimum of $0 \mathrm{~h} 37$ and a maximum of almost 2 days.

Table 5

Measures of central tendency and dispersion concerning AMI patients' DTt

\begin{tabular}{lcccc}
\hline Time & Group & Mean $( \pm S D)$ & Min & Max \\
\hline \multirow{2}{*}{ Symptoms-admission } & NSTEMI $(n=213)$ & $3 \mathrm{~h} 49( \pm 4 \mathrm{~h} 02)$ & $0 \mathrm{~h} 15$ & $23 \mathrm{~h} 15$ \\
& STEMI $(n=127)$ & $3 \mathrm{~h} 43( \pm 4 \mathrm{~h} 10)$ & $0 \mathrm{~h} 06$ & $23 \mathrm{~h} 15$ \\
& Total $(n=340)$ & $3 \mathrm{~h} 47( \pm 4 \mathrm{~h} 04)$ & $0 \mathrm{~h} 06$ & $23 \mathrm{~h} 15$ \\
\hline Admission-ECG & NSTEMI $(n=265)$ & $2 \mathrm{~h} 00( \pm 2 \mathrm{~h} 36)$ & $0 \mathrm{~h} 01$ & $15 \mathrm{~h} 04$ \\
& $\operatorname{STEMI}(n=139)$ & $1 \mathrm{~h} 02( \pm 1 \mathrm{~h} 26)$ & $0 \mathrm{~h} 02$ & $9 \mathrm{~h} 51$ \\
\hline Admission-fibrinolysis & Total $(n=404)$ & $1 \mathrm{~h} 40( \pm 2 \mathrm{~h} 18)$ & $0 \mathrm{~h} 01$ & $15 \mathrm{~h} 04$ \\
\hline Admission- & STEMI $(n=12)$ & $1 \mathrm{~h} 19( \pm 0 \mathrm{~h} 40)$ & $0 \mathrm{~h} 37$ & $2 \mathrm{~h} 24$ \\
Primary PCI & STEMI $(n=114)$ & $7 \mathrm{~h} 19( \pm 8 \mathrm{~h} 20)$ & $0 \mathrm{~h} 37$ & $1 \mathrm{~d}+23 \mathrm{~h} 21$ \\
\hline
\end{tabular}

Note. $S D=$ standard deviation $; n=$ sample; $\mathrm{Min}=$ minimum; $\mathrm{Max}=$ maximum.

Table 6 shows the results of the Mann-Whitney $U$ test for comparison of the time elapsed between admission and ECG according to gender, period of the day, and weekday. Only statistically significant differences $(p<0.05)$ were found in the subsample of NSTEMI patients, namely that the men underwent ECG monitoring $0 \mathrm{~h} 38$ sooner than women.

Table 6

Results of the Mann-Whitney $U$ test for comparison between the time elapsed between admission and ECG according to gender, period of the day, weekday, and type of AMI

\begin{tabular}{llcccc}
\hline Admission - ECG & & Mean $( \pm S D)$ & Median & $\mathrm{X}^{2}$ & $p$ \\
\hline \multirow{2}{*}{$\begin{array}{l}\text { NSTEMI } \\
(n=265)\end{array}$} & $\begin{array}{l}\text { Men } \\
(n=170)\end{array}$ & $1 \mathrm{~h} 46 \pm 2 \mathrm{~h} 24$ & $0 \mathrm{~h} 49$ & & \\
\cline { 2 - 4 } & $\begin{array}{l}\text { Women } \\
(n=95)\end{array}$ & $2 \mathrm{~h} 24 \pm 2 \mathrm{~h} 52$ & $1 \mathrm{~h} 21$ & & 0.0235 .5 \\
\hline
\end{tabular}




\begin{tabular}{|c|c|c|c|c|c|}
\hline \multirow{2}{*}{ STEMI $(n=139)$} & $\begin{array}{l}\text { Men } \\
(n=106)\end{array}$ & $1 \mathrm{~h} 00 \pm 1 \mathrm{~h} 29$ & oh31 & \multirow{2}{*}{1.909 .5} & \multirow{2}{*}{0.427} \\
\hline & $\begin{array}{l}\text { Women } \\
(n=33)\end{array}$ & $1 \mathrm{~h} 08 \pm 1 \mathrm{~h} 17$ & $0 \mathrm{~h} 42$ & & \\
\hline \multirow{2}{*}{$\begin{array}{l}\text { NSTEMI } \\
(n=265)\end{array}$} & $\begin{array}{l}\text { Day } \\
(n=154)\end{array}$ & $1 \mathrm{~h} 33 \pm 1 \mathrm{~h} 36$ & oh56 & \multirow{2}{*}{7.806 .0} & \multirow{2}{*}{0.229} \\
\hline & $\begin{array}{l}\text { Night } \\
(n=111)\end{array}$ & $2 \mathrm{~h} 36 \pm 3 \mathrm{~h} 27$ & $0 \mathrm{~h} 50$ & & \\
\hline \multirow{2}{*}{$\begin{array}{l}\text { STEMI } \\
(n=139)\end{array}$} & $\begin{array}{l}\text { Day } \\
(n=91)\end{array}$ & $1 \mathrm{~h} 04 \pm 1 \mathrm{~h} 27$ & oh31 & \multirow{2}{*}{2.287 .5} & \multirow{2}{*}{0.647} \\
\hline & $\begin{array}{l}\text { Night } \\
(n=48)\end{array}$ & $0 \mathrm{~h} 58 \pm 1 \mathrm{~h} 25$ & oh33 & & \\
\hline \multirow{2}{*}{$\begin{array}{l}\text { NSTEMI } \\
(n=265)\end{array}$} & $\begin{array}{l}\text { Weekend } \\
(n=79)\end{array}$ & $1 \mathrm{~h} 46 \pm 2 \mathrm{~h} 00$ & oh 58 & \multirow{2}{*}{7.338 .0} & \multirow{2}{*}{0.987} \\
\hline & $\begin{array}{l}\text { Week } \\
(n=186)\end{array}$ & $2 \mathrm{~h} 05 \pm 2 \mathrm{~h} 48$ & oh 52 & & \\
\hline \multirow{2}{*}{$\begin{array}{l}\text { STEMI } \\
(n=139)\end{array}$} & $\begin{array}{l}\text { Weekend } \\
(n=35)\end{array}$ & $0 \mathrm{~h} 58 \pm 1 \mathrm{~h} 11$ & oh31 & \multirow{2}{*}{1.854 .0} & \multirow{2}{*}{0.869} \\
\hline & $\begin{array}{l}\text { Week } \\
(n=104)\end{array}$ & $1 \mathrm{~h} 03 \pm 1 \mathrm{~h} 31$ & oh33 & & \\
\hline
\end{tabular}

Note. $S D=$ standard deviation; $n=$ sample; $\mathrm{X}^{2}=$ chi-square test.

In relation to age and the type of transport and their association with the time elapsed between admission to the ED and ECG, Table 7 shows that, on average, NSTEMI patients aged [61 - 70] years performed the ECG 1 h 19 sooner than patients aged $\geq 81$ years, whereas STEMI patients aged $\leq 50$ years and [51 - 60] years perform the ECG sooner than patients aged $\geq 81$ years. In relation to the type of transport, statistically significant differences $(p<0.05)$ were found in both subsamples, with patients transported by ILS/VMER performing the ECG sooner.

Table 7

Results of the Kruskal-Wallis test for comparison of the DTt between admission and ECG according to the age group, type of transport, and type of AMI

\begin{tabular}{|c|c|c|c|c|c|c|}
\hline $\begin{array}{l}\text { Admission } \\
\text { - ECG }\end{array}$ & & Mean $( \pm S D)$ & Median & Comp. & $\mathrm{X}^{2}$ & $p$ \\
\hline \multirow{5}{*}{$\begin{array}{l}\text { NSTEMI } \\
(n=265)\end{array}$} & $\begin{array}{l}\text { a) } \leq 50 \text { years } \\
(n=21)\end{array}$ & $2 \mathrm{~h} 01 \pm 3 \mathrm{~h} 08$ & $0 \mathrm{~h} 44$ & -- & \multirow{5}{*}{10.117} & \multirow{5}{*}{0.039} \\
\hline & $\begin{array}{l}\text { b) } 51-60 \text { years } \\
(n=45)\end{array}$ & $1 \mathrm{~h} 56 \pm 2 \mathrm{~h} 14$ & $1 \mathrm{~h} 02$ & -- & & \\
\hline & $\begin{array}{l}\text { c) } 61-70 \text { years } \\
(n=56)\end{array}$ & $1 \mathrm{~h} 12 \pm 1 \mathrm{~h} 23$ & $0 \mathrm{~h} 33$ & $\mathrm{c}<\mathrm{e}$ & & \\
\hline & $\begin{array}{l}\text { d) } 71-80 \text { years } \\
(n=73)\end{array}$ & $2 \mathrm{~h} 08 \pm 2 \mathrm{~h} 39$ & $0 \mathrm{~h} 53$ & -- & & \\
\hline & $\begin{array}{l}\text { e) } \geq 81 \text { years } \\
(n=70)\end{array}$ & $2 \mathrm{~h} 31 \pm 3 \mathrm{~h} 10$ & $1 \mathrm{~h} 10$ & $e>c$ & & \\
\hline
\end{tabular}




\begin{tabular}{|c|c|c|c|c|c|c|}
\hline \multirow{5}{*}{$\begin{array}{l}\text { STEMI } \\
(n=139)\end{array}$} & $\begin{array}{l}\text { a) } \leq 50 \text { years } \\
(n=29)\end{array}$ & $0 \mathrm{~h} 49 \pm 1 \mathrm{~h} 13$ & oh31 & $\mathrm{a}<\mathrm{e}$ & \multirow{5}{*}{11.547} & \multirow{5}{*}{0.021} \\
\hline & $\begin{array}{l}\text { b) } 51-60 \text { years } \\
(n=21)\end{array}$ & $0 \mathrm{~h} 36 \pm 0 \mathrm{~h} 37$ & $0 \mathrm{~h} 21$ & $\mathrm{~b}<\mathrm{e}$ & & \\
\hline & $\begin{array}{l}\text { c) } 61-70 \text { years } \\
(n=41)\end{array}$ & $1 \mathrm{~h} 02 \pm 1 \mathrm{~h} 27$ & oh31 & - & & \\
\hline & $\begin{array}{l}\text { d) } 71-80 \text { years } \\
(n=27)\end{array}$ & oh59 \pm 1 h09 & $0 \mathrm{~h} 27$ & -- & & \\
\hline & $\begin{array}{l}\text { e) } \geq 81 \text { years } \\
(n=21)\end{array}$ & $1 \mathrm{~h} 51 \pm 2 \mathrm{~h} 13$ & 1h03 & $\begin{array}{l}e>b \\
e>a\end{array}$ & & \\
\hline \multirow{3}{*}{$\begin{array}{l}\text { NSTEMI } \\
(n=182)\end{array}$} & a) $\operatorname{INEM}(n=108)$ & $2 \mathrm{~h} 17 \pm 2 \mathrm{~h} 46$ & $1 \mathrm{~h} 08$ & $a>c$ & \multirow{3}{*}{15.601} & \multirow{3}{*}{$<0.001$} \\
\hline & $\begin{array}{l}\text { b) Own transport } \\
(n=40)\end{array}$ & $1 \mathrm{~h} 43 \pm 1 \mathrm{~h} 50$ & $0 \mathrm{~h} 55$ & $\mathrm{~b}>\mathrm{c}$ & & \\
\hline & $\begin{array}{l}\text { c) ILS/VMER } \\
(n=34)\end{array}$ & $1 \mathrm{~h} 50 \pm 3 \mathrm{~h} 51$ & oh18 & $\begin{array}{l}c<a \\
c<b\end{array}$ & & \\
\hline \multirow{3}{*}{$\begin{array}{l}\text { STEMI } \\
(n=95)\end{array}$} & a) $\operatorname{INEM}(n=41)$ & $0 \mathrm{~h} 49 \pm 0 \mathrm{~h} 52$ & 0h33 & $a>c$ & \multirow{3}{*}{19.426} & \multirow{3}{*}{$<0.001$} \\
\hline & $\begin{array}{l}\text { b) Own transport } \\
(n=30)\end{array}$ & $0 \mathrm{~h} 55 \pm 1 \mathrm{~h} 11$ & $0 \mathrm{~h} 28$ & $\mathrm{~b}>\mathrm{c}$ & & \\
\hline & $\begin{array}{l}\text { c) ILS/VMER } \\
(n=24)\end{array}$ & $0 \mathrm{~h} 15 \pm 0 \mathrm{~h} 17$ & oh 10 & $\begin{array}{l}c<a \\
c<b\end{array}$ & & \\
\hline
\end{tabular}

Note. $S D=$ standard deviation; $n=$ sample; Comp. = pairwise multiple comparison tests; $\mathrm{X}^{2}=$ chi-square test .

With regard to the association between the presence of CVRFs and cardiac history and the time elapsed between admission and ECG (Table 8), only statistical significant differences $(p<0.05)$ were found in the sample of smokers and former smokers who underwent ECG on average 0h18 sooner than non-smokers. On the contrary, diabetic STEMI patients performed the ECG later than non-diabetic patients. 
Table 8

Results of the Mann-Whitney U-test for comparison of the DTt between admission and ECG according to the presence of risk factors, cardiac history, and type of AMI

\begin{tabular}{|c|c|c|c|c|c|c|}
\hline & Sample & Presence & $\begin{array}{l}\text { Mean } \\
( \pm S D)\end{array}$ & Median & $\mathrm{X}^{2}$ & Sig. \\
\hline \multirow{6}{*}{ Smoking } & \multirow{2}{*}{$\begin{array}{l}\text { NSTEMI } \\
(n=265)\end{array}$} & Yes $(n=97)$ & $2 \mathrm{~h} 01 \pm 2 \mathrm{~h} 47$ & oh51 & \multirow{2}{*}{7.836 .5} & \multirow{2}{*}{0.604} \\
\hline & & No $(n=168)$ & $1 \mathrm{~h} 59 \pm 2 \mathrm{~h} 29$ & 1h02 & & \\
\hline & \multirow{2}{*}{$\begin{array}{l}\text { STEMI } \\
(n=139)\end{array}$} & Yes $(n=68)$ & $0 \mathrm{~h} 44 \pm 0 \mathrm{~h} 54$ & 0h26 & \multirow{2}{*}{1.971 .5} & \multirow{2}{*}{0.062} \\
\hline & & No $(n=71)$ & $1 \mathrm{~h} 19 \pm 1 \mathrm{~h} 46$ & 0h39 & & \\
\hline & \multirow{2}{*}{$\begin{array}{l}\text { Total } \\
(n=404)\end{array}$} & Yes $(n=165)$ & $1 \mathrm{~h} 29 \pm 2 \mathrm{~h} 18$ & 0h40 & \multirow{2}{*}{17.265 .5} & \multirow{2}{*}{0.033} \\
\hline & & No $(n=239)$ & $1 \mathrm{~h} 47 \pm 2 \mathrm{~h} 19$ & oh52 & & \\
\hline \multirow{6}{*}{$\begin{array}{l}\text { Diabetes } \\
\text { mellitus }\end{array}$} & \multirow{2}{*}{$\begin{array}{l}\text { NSTEMI } \\
(n=265)\end{array}$} & Yes $(n=94)$ & $2 \mathrm{~h} 11 \pm 3 \mathrm{~h} 07$ & $0 \mathrm{~h} 52$ & \multirow{2}{*}{8.012 .5} & \multirow{2}{*}{0.967} \\
\hline & & No $(n=171)$ & $1 \mathrm{~h} 53 \pm 2 \mathrm{~h} 16$ & $0 \mathrm{~h} 56$ & & \\
\hline & \multirow{2}{*}{$\begin{array}{l}\text { STEMI } \\
(n=139)\end{array}$} & Yes $(n=32)$ & $1 \mathrm{~h} 02 \pm 0 \mathrm{~h} 46$ & 0h58 & \multirow{2}{*}{2.168 .5} & \multirow{2}{*}{0.022} \\
\hline & & No $(n=107)$ & $1 \mathrm{~h} 02 \pm 1 \mathrm{~h} 35$ & oh26 & & \\
\hline & \multirow{2}{*}{$\begin{array}{l}\text { Total } \\
(n=404)\end{array}$} & Yes $(n=126)$ & $1 \mathrm{~h} 53 \pm 2 \mathrm{~h} 45$ & 0h54 & \multirow{2}{*}{19.247 .5} & \multirow{2}{*}{0.111} \\
\hline & & No $(n=278)$ & $1 \mathrm{~h} 34 \pm 2 \mathrm{~h} 04$ & 0h44 & & \\
\hline \multirow{6}{*}{ НВР } & \multirow{2}{*}{$\begin{array}{l}\text { NSTEMI } \\
(n=265)\end{array}$} & Yes $(n=194)$ & $2 \mathrm{~h} 00 \pm 2 \mathrm{~h} 36$ & oh52 & \multirow{2}{*}{6.769 .0} & \multirow{2}{*}{0.831} \\
\hline & & No $(n=71)$ & $2 \mathrm{~h} 00 \pm 2 \mathrm{~h} 35$ & $1 \mathrm{~h} 01$ & & \\
\hline & \multirow{2}{*}{$\begin{array}{l}\text { STEMI } \\
(n=139)\end{array}$} & Yes $(n=82)$ & $1 \mathrm{~h} 00 \pm 1 \mathrm{~h} 26$ & 0h31 & \multirow{2}{*}{2.316 .0} & \multirow{2}{*}{0.928} \\
\hline & & No $(n=57)$ & $1 \mathrm{~h} 04 \pm 1 \mathrm{~h} 26$ & 0h33 & & \\
\hline & Total & Yes $(n=276)$ & $1 \mathrm{~h} 42 \pm 2 \mathrm{~h} 21$ & 0h45 & 181545 & 0653 \\
\hline & $(n=404)$ & No $(n=128)$ & $1 \mathrm{~h} 35 \pm 2 \mathrm{~h} 12$ & 0h49 & 18.154 .5 & 0.653 \\
\hline & NSTEMI & Yes $(n=153)$ & $1 \mathrm{~h} 48 \pm 2 \mathrm{~h} 25$ & oh51 & 74665 & 0074 \\
\hline & $(n=265)$ & No $(n=112)$ & $2 \mathrm{~h} 16 \pm 2 \mathrm{~h} 49$ & $1 \mathrm{~h} 04$ & 1.406 .5 & $0.0 / 4$ \\
\hline & STEMI & Yes $(n=78)$ & $1 \mathrm{~h} 02 \pm 1 \mathrm{~h} 12$ & 0h39 & & \\
\hline Dyslipidemia & $(n=139)$ & No $(n=61)$ & $1 \mathrm{~h} 02 \pm 1 \mathrm{~h} 42$ & oh24 & 2.789 .0 & 0.082 \\
\hline & Total & Yes $(n=231)$ & $1 \mathrm{~h} 32 \pm 2 \mathrm{~h} 07$ & $0 \mathrm{~h} 46$ & 104500 & 0652 \\
\hline & $(n=404)$ & No $(n=173)$ & $1 \mathrm{~h} 50 \pm 2 \mathrm{~h} 32$ & 0h44 & 19.458 .0 & 0.652 \\
\hline & NSTEMI & Yes $(n=61)$ & $2 \mathrm{~h} 01 \pm 2 \mathrm{~h} 11$ & $1 \mathrm{~h} 07$ & 67985 & 0272 \\
\hline & $(n=265)$ & No $(n=204)$ & $1 \mathrm{~h} 59 \pm 2 \mathrm{~h} 42$ & oh52 & 6.798 .5 & 0.272 \\
\hline & STEMI & Yes $(n=26)$ & $1 \mathrm{~h} 23 \pm 2 \mathrm{~h} 10$ & 0h33 & 16480 & 0334 \\
\hline Overweight & $(n=139)$ & No $(n=113)$ & $0 \mathrm{~h} 57 \pm 1 \mathrm{~h} 12$ & 0h31 & 1.648 .0 & 0.334 \\
\hline & Total & Yes $(n=87)$ & $1 \mathrm{~h} 49 \pm 2 \mathrm{~h} 11$ & $0 \mathrm{~h} 56$ & & 0000 \\
\hline & $(n=404)$ & No $(n=317)$ & $1 \mathrm{~h} 37 \pm 2 \mathrm{~h} 20$ & 0h44 & 15.428 .0 & 0.089 \\
\hline & NSTEMI & Yes $(n=82)$ & $2 \mathrm{~h} 01 \pm 3 \mathrm{~h} 12$ & $0 \mathrm{~h} 45$ & 6475 & 002 \\
\hline & $(n=265)$ & No $(n=183)$ & $1 \mathrm{~h} 59 \pm 2 \mathrm{~h} 17$ & $1 \mathrm{~h} 05$ & $0.42 / .5$ & 0.002 \\
\hline Cardiac & STEMI & Yes $(n=21)$ & $1 \mathrm{~h} 18 \pm 2 \mathrm{~h} 23$ & 0h28 & 1400 & 0560 \\
\hline history & $(n=139)$ & No $(n=118)$ & $0 \mathrm{~h} 59 \pm 1 \mathrm{~h} 12$ & oh33 & 1.140 .0 & 0.560 \\
\hline & Total & Yes $(n=103)$ & $1 \mathrm{~h} 52 \pm 3 \mathrm{~h} 03$ & 0h44 & 114205 & טרקת \\
\hline & $(n=404)$ & No $(n=301)$ & $1 \mathrm{~h} 36 \pm 1 \mathrm{~h} 59$ & oh50 & 14.438 .5 & 0.229 \\
\hline
\end{tabular}

Note. $S D=$ standard deviation; $n=$ sample; $\mathrm{X}^{2}=$ chi-square test Sig. = significance. 
Table 9 shows the comparison of the time elapsed between admission and primary PCI based on the period of the day and weekday. Statistically significant differences $(p<0.05)$ were found in patients who used the ED during the day period, as they were treated on average of $2 \mathrm{~h} 37$ sooner than those who used the ED in the night period.

Table 9

Results of the Mann-Whitney U-test for comparison of STEMI patients' door-to-balloon time (time elapsed between admission and primary PCI) according to the period of the day/weekday

\begin{tabular}{lllll}
\hline $\begin{array}{l}\text { Admission- } \\
\text { primary PCI }\end{array}$ & $\begin{array}{c}\text { Mean } \\
( \pm S D)\end{array}$ & Median & X & Sig. \\
\cline { 1 - 3 } Day period $(n=79)$ & $6 \mathrm{~h} 31 \pm 8 \mathrm{~h} 55$ & $3 \mathrm{~h} 04$ & 830.500 & 0.001 \\
\cline { 1 - 3 } Night period $(n=35)$ & $9 \mathrm{~h} 08 \pm 7 \mathrm{~h} 30$ & $8 \mathrm{~h} 01$ & 1.380 .0 & 0.552 \\
\hline Weekend $(n=31)$ & $7 \mathrm{~h} 29 \pm 8 \mathrm{~h} 17$ & $3 \mathrm{~h} 34$ & $3 \mathrm{~h} 25$ & \\
\hline Week $(n=83)$ & $7 \mathrm{~h} 16 \pm 8 \mathrm{~h} 43$ & & & \\
\hline
\end{tabular}

Note. $S D=$ standard deviation; $n=$ sample; $\mathrm{X}^{2}=$ chi-square test; Sig. = significance.

\section{Discussion}

This study included 412 people, mostly men (68.9\%), aged 29 to 97 years, with a mean age of 68.4 years. However, the analysis of the subsamples showed that the largest number of STEMI cases were found in the [61 - 70] age group $(30.1 \%)$, while the largest number of NSTEMI cases were found in the [71 - 80] age group (27.4\%). The data obtained are consistent with the European reality. In 2014 around 1.4 million people aged less than 75 years die from CVDs (Sousa, 2015).

The mean time elapsed between symptom onset and admission to the ED was of $3 \mathrm{~h} 47$, which is a result that meets the current standards. In a study conducted in 2010 and 2011, Carapeto (2012) obtained a mean DTt (time elapsed between symptom onset and first medical observation) of 1 h55 in 2011 and $2 \mathrm{~h} 16$ in 2012.

As regards the time elapsed between admission to the ED and ECG, the mean time was 1 h40. In NSTEMI patients, the mean time increases to $2 \mathrm{~h} 00$, whereas in STEMI patients it decreases to $1 \mathrm{~h} 02$. Other authors conducted similar studies and obtained better results, namely Gouvêa, Reis, Gouvêa, Lima, and Abuabara (2015) who measured the time elapsed between admission to the ED and triage and between triage and ECG and obtained a mean time of $0 \mathrm{~h} 37$.
Therefore, this study aimed to identify the factors reducing this time and found that, on average, only male NSTEMI patients undergo an ECG 0h38 sooner than female patients. With regard to age, it was clear that, on average, NSTEMI patients in the [61 - 70] age range undergo an ECG 1 h19 sooner than patients aged $\geq 81$ years, as well as STEMI patients aged $\leq 50$ years $(1 \mathrm{~h} 02)$ and [51 - 60] years (1h15), when compared to the other patients aged $\geq 81$ years.

In Portugal, in 2012, of the people under the age of 65 years who died of ischemic heart disease, $81 \%$ were men and only $19 \%$ were women, and of those under the age 70 years, $77.6 \%$ were men and $22.4 \%$ were women. In addition, the mean age of death from CVD is 78 years in men and 83 years in women (Instituto Nacional de Estatística [INE], 2014). Therefore, it is likely that male patients use the ED earlier in life, a fact which, together with health professionals' awareness of male patients' higher risk level, can contribute to reduce the DTt in men.

This study also aimed to identify the association between the door-to-ECG time and the variables CVRFs and cardiac history. This study found that the time only reduced significantly (on average 0h18) in smokers or former smokers when compared to people who never smoked. The analysis of the subsamples only showed a statistically significant 
difference in diabetic STEMI patients, with an increased time elapsed between admission and ECG. The period of the day and weekday in which the person used the ED was also compared with the time elapsed between admission and ECG, but no statistically significant difference was observed.

The transport used to get to the ED also influenced the time elapsed between admission and ECG, since patients transported by ILS/ VMER underwent an ECG sooner in both subsamples. These results were expected, since people transported by ILS/VMER are directly admitted to the ED and, consequently, they are immediately triaged and observed. In this study, the mean door-to-balloon time (primary PCI), which was another research focus, was of 7 h19. In a study conducted on this topic between July 2005 and June 2009 in the United States, Menees et al. (2013) concluded that the mean time decreased from $1 \mathrm{~h} 23$ in 2005 to 1 h07 in 2009. In 2010, Carapeto (2012) reported door-to-balloon times between $0 \mathrm{~h} 46$ and $8 \mathrm{~h} 44$. The author also compared the people who were transported by INEM to the ED and those who used other means of transport and found that the door-to-balloon time of patients transported by INEM was $0 \mathrm{~h} 59$ and that of the other patients was $2 \mathrm{~h} 30$. Similarly, in 2011, the mean time of patients transported by INEM to the ED was of $1 \mathrm{~h} 09$ and that of those who arrived by other means of transport was of $2 \mathrm{~h} 13$. These studies found lower door-to-balloon times than this study; however, this study did not include people who were referred by CODU (via verde coronária), because the time would certainly be lower if these patients were included.

As regards the factors involved in reducing the door-to-balloon time (primary PCI), this study only showed statistically significant differences in the day period, when patients were examined on average $2 \mathrm{~h} 37$ sooner than during the night period. Other authors have studied the association between DTt and the period of the day and obtained similar results, namely, Magid et al. (2005) who concluded that the DTt is longer between $17 \mathrm{~h} 00$ and 7h00. The time elapsed between admission and fibrinolysis could not be analyzed due to the small sample size.

\section{Conclusion}

The data collected in this study are in line with the current situation of CVDs, both in Portugal and in Europe. This study found that $65 \%$ of the patients had NSTEMI and $35 \%$ of them had STEMI. A total of $49.1 \%$ of patients were in the age range [61 - 80] years, with a predominance of male patients (68.9\%). The most prevalent CVRFs was HBP $(68.7 \%)$ and the most relevant cardiac history was AMI (16\%).

In the total sample, the factors influencing the reduction of the time elapsed between admission and ECG were the smoking history and the transport by ILS/VMER. In the subsample of NSTEMI patients, the time was lower in male patients and in those aged [61 - 70] years. In the subsample of STEMI patients, the time was lower in non-diabetic patients and in those aged [29 - 60] years. The time elapsed between admission and primary PCI was only influenced by the day period variable.

The fact that this study was a retrospective study has limited the analysis of other variables that could influence DTt. However, it showed the reality experienced in this ED, thus allowing to identify limitations and intervene to overcome them.

Therefore, multidisciplinary teams should reflect on and further analyze professional practices of caring for AMI patients and, consequently, implement the necessary changes, particularly through the introduction of protocols to quickly identify and treat STEMI patients at the ED. In addition, professionals should promote the development of more studies in this area, preferably after the changes have been implemented, with the purpose of identifying the benefits achieved.

\section{References}

American College of Cardiology Foundation (ACCF) / American Heart Association (AHA). (2013). 2013 ACCF/AHA Guideline for the Management of ST-Elevation Myocardial Infarction. A Report of the American College of Cardiology Foundation/ American Heart Association Task Force on Practice Guidelines. Circulation, 127, 362-425. doi: 10.1161/CIR.0b013e3182742cf6 
Carapeto, S. (2012). Via Verde Coronária e Enfarte Agudo do Miocárdio: Tempo médio entre a admissão no Serviço de Urgência Central e a reperfusão por Angioplastia Primária (Master's dissertation). Faculdade de Medicina da Universidade de Lisboa, Portugal.

Direcção-Geral da Saúde. (2014). Portugal-Doenças Cérebro-Cardiovasculares em números - 2014. Lisboa, Portugal. DC: Autor. ISSN: 2183-0681

European Society of Cardiology. (2012). EAM - STEMI. Recomendaçóes para o tratamento do enfarte agudo do miocárdio em doentes com elevação persistente do segmento ST. France: Autor.

Gouvêa, V.E., Reis, M.A., Gouvêa, G., Lima, H., \& Abuabara, A. (2015). Avaliação do Sistema de Triagem de Manchester na Síndrome Coronariana Aguda. International Journal of Cardiovascular Sciences, 28(2), 107-113. Retrieved from http://www. onlineijcs.org/exportar-pdf/387/v28n2a05.pdf doi: $10.5935 / 2359-4802.20150019$

Instituto Nacional de Estatística. (2014). Risco de Morrer 2012. INE, I.P., Lisboa. Portugal.

Kanth. R., Ittaman, S. \& Rezkalla, S. (2013). Circadian Patterns of ST Elevation Myocardial Infarction in the New Millennium. Clinical Medicine \& Research, 11(2), 66-72. Retrieved from http://www.clinmed- res.org/content/11/2/66.full.pdf.

Kostis, W., Demissie, K., Marcella, S., Shao, Y., Wilson, A. \& Moreyra, A. (2007). Weekend versus Weekday Admission and Mortality from Myocardial Infarction. The new england journal of medicine, 356 (11), 1099-1109. Retrieved from www.nejm.org.

Magid, D., Wang, Y.,Herrin, J., McNamara, R., Bradley, E., Curtis, J., ...Krumholz, H. (2005). Relationship between time of day, day of week, timeliness of reperfusion, and in-hospital mortality for patients with acute ST-segment elevation myocardial infarction. JAMA, 294(7), 803-812. Retrieved from http://www. ncbi.nlm.nih.gov/pubmed/16106005

Menees, D., Peterson, E., Wang, Y., Curtis, J., Messenger, J., Rumsfeld, J., \& Gurm, H. (2013). Doorto-Balloon Time and Mortality among Patients Undergoing Primary PCI. The new england journal of medicine, 369(10). Retrieved from http://www. nejm.org/doi/pdf/10.1056/NEJMoa1208200.

Sousa, P. (2015). Comentário a «Doença Cardiovascular na Europa em 2014: atualização dos resultados epidemiológicos». Revista Portuguesa de Cardiologia, 34(5), 381-382. Retrieved from http://www. elsevier.pt/pt/revistas/revista-portuguesa-cardiologia-334/pdf/S0870255115001055/S300/ 